\title{
Effect of Laurusnobilis extract and Atorvastatin on Liver and Kidney function of Hyperlipidemia Male Rats
}

\author{
Faraj Hato \\ Lecture, Physiology, Medical Technical Institute- Medical Technical University (MTU). Baghdad. Iraq
}

\begin{abstract}
Introduction: Hyperlipidemia associated with increase of atherosclerosis and heart, blood vessels diseases. the present study was discuss of potentials effect of bay leave extract (BLE) and atorvastatin drug at diet with high fat, feeding rat types. Material and Methods: The Rats were randomly classificationfor 4 groups each group have 10 rats. control feed standard diet, group two rats feed HFD, group three rats feed HFD + ( BLE $250 \mathrm{mg} / \mathrm{kg}$ ) and group four rats feed HFD + Atorvastatin $20 \mathrm{mg} / \mathrm{kg}$ in the experiment, the treatment done by gavage and treated with 4 weeks daily. Results and Conclusion: The results show increased significantly at the end body weights also the weight gain at group two by treated (HFD), while hepatic levels was inhibited for the cholesterol, and also triglycerides, also the low-density lipoprotein cholesterol; While the hepatic levels and serum of high-density lipoprotein cholesterol may be increased when the animal treated $250 \mathrm{mg} / \mathrm{kg} \mathrm{BLE}$ and $20 \mathrm{mg} / \mathrm{kg}$ atorvastatin, also the result showed increased significantly in serum AST ,ALT, ALP, urea and creatinine in group of animals treated HFD , and caused decreased significantly in the value of above parameters when the animals treated $250 \mathrm{mg} / \mathrm{kg} \mathrm{BLE}$ and $20 \mathrm{mg} / \mathrm{kg}$ atorvastatin ,it reach the control. In conclusion, bay leave exerts and atorvastatin have amelioration effect against hyperlipidemia in HFD-fed rats.
\end{abstract}

Keywords: Hyperlipidemia, Laurusnobilis, Atorvastatin, Lipid profile

\section{Introduction}

Hyperlipidemia is specially called hypercholesterolemia, that is risk factor to increase for heart and blood vessels disease, hyperlipidemia, common of cause the mortality worldwide, it is high risk factor to many disease like related cardiovascular and atherosclerosis, which is include the coronary heart disease, and disease of brain, also myocardial infarction (IM), kidney failure which is major health problem at the world ${ }^{1}$. Lipids contain cholesterol, cholesterol esters, triglycerides and phospholipids. levels of LDL which is increased due to related to appear of atherosclerosis ${ }^{2}$. The removing cholesterol from

\section{Corresponding author:}

\section{Faraj Hato}

email is: faraj.phd@gmail.com tissues and highly protected against cardiovascular disease these by high density lipoprotein, resulted the hyperlipidemia means to high levels of lipids which are include the triglycerides and cholesterol or both at blood, high triglycerides concentration in blood means hyper triglyceridemia, but the cholesterol concentration in blood means hypercholesterolemia ${ }^{3}$. Other condition called dyslipidemia which is means abnormal metabolism of lipoprotein metabolism, which is related to increase production of lipoprotein or deficiency, these abnormalities lead to increase of total cholesterol in serum, triglyceride and low density lipoprotein concentration but low level of high density lipoprotein concentration, hyperlipidemia treated is reduce the risk of heart disease, blood vessels diseases and brain diseases ${ }^{4}$. The main source of cholesterol will not be diet, but about $80 \%$ of cholesterol is formed in the body. The diet intake 
affects totally on the amount of cholesterol somewhat ${ }^{5}$, the cholesterol may synthesized endogenously with organs such as liver and others organs. Some disease such as Endocrine disease most common to cause of hyperlipidemia ${ }^{6}$, also hyperlipidemia can occurred due to an inherited disease such as in some breeds of dogs 7. Laurusnobilis (bay leaf) (BL), called as laurel leaf, it is a fixture in cooking at many cuisines specially at Mediterranean also in the Americas, the leaves also ground before cooking, by leaf as plant used in many industrial, this used in many appliedsuch as drugs and foods also in cosmetics, the oils and leaves with dried which are used in food industry for adaptation meat products and fishes. It contain of essential oils about 1.3 percent. The leaves not permit growth of models, By leaves are pungent and taste with bitter if leaf is dried the aroma is herbal, also By leaves used in making of jerk chicken at Caribbean islands, the leaves was soaked and placed on col side for grill ${ }^{8}$. The term of tannin is a class of astringent, which is precipitate proteins and other organic compounds such as alkaloids and proteins, the compounds of tannin are distributed for several species of plants, they important in protection from predation also in regulation of plant growth, contraction from tannins is what lead to dry and pucker feeling in mouth throw the consumption of un ripened fruit, the tannins have the molecular weight vary from 500 to over 3,000 and up to 20,000 Daltons ${ }^{9}$. The Tanine derivative from part of plants which are found in market, it is cream colored powder, astringent taste and aromatic ${ }^{10}$.

\section{Material and Methods}

The sample about 40 rats (male), the age between 6-8 weeks and the weight between 180-200 g the rats were collected in animal house of science college of Thi- Qar, by environmental control rats were housed in animal house about 12- hour light and dark remain for one week and the rats acclimatization before experiments.

Groups of animals lab: It classified to four of groups ( $\mathrm{n}=10$ per group) which are including the control group called (normal) one given normal slandered diet, the group two given diet with high fat, the group three the rats which is given HFD and treated with BLE $250 \mathrm{mg} / \mathrm{kg}$ and group four the animals given HFD and treated with atorvastatin 20 $\mathrm{mg} / \mathrm{kg}$; also the animals were given ad libitum access to diet with high fat for 4 of weeks, but not the normal group, maybe taking the control diet with end the rats were anesthetized also sacrificed.

\section{Preparation of Bay leaf extract}

Preparation of Bay leaf in the first carefully wash and dry of all leaves and put the leaves in container about half of bay leaves and oil and closed put the container in a pan and fill to $2 \mathrm{~cm}$ above of top container in the end bring to boil simmer slowly at two hours .

\section{Results}

Table (1), show is no significantly difference $(\mathrm{P}>0.05)$ in the body weight (initial) of all groups. Final body weight was significantly increased $(\mathrm{P}<0.05)$ in hyperlipidemia group as to compared by control and others groups with treated. Weight gain was significantly also increased $(\mathrm{P}<0.05)$ in group of animal given high fat diet to compare by control and others groups. 
Table1. Effect of bay leave extract and atorvastatin on hyperlipidemia male rats on B.W gains (Mean \pm SD) $\mathbf{n}=\mathbf{1 0}$.

\begin{tabular}{|c|c|c|c|}
\hline The treatment & Initial B.W. (g) & Final B.W (g) & Weight gain (g) \\
\hline Group ( control) & $259.04 \pm 8.41$ & $\begin{array}{c}282.83 \pm 12.18 \\
\text { A }\end{array}$ & $\begin{array}{c}23.79 \pm 1.41 \\
\text { b }\end{array}$ \\
\hline HFD $2 \%$ cholesterol & $261.42 \pm 1.60$ & $\begin{array}{c}318.11 \pm 1.23 \\
\text { A }\end{array}$ & $\begin{array}{c}56.69 \pm 1.13 \\
\text { A }\end{array}$ \\
\hline BLE $250 \mathrm{mg} / \mathrm{kg}$ & $255.13 \pm 10.86$ & $279.11 \pm 12.45$ & $23.98 \pm 0.89$ \\
Atorvastatin $20 \mathrm{mg} / \mathrm{kg}$ & $257.12 \pm 1.7$ & $\mathrm{~B}$ & $36.30 \pm 1.53$ \\
& $\mathrm{~A}$ & $293.42 \pm 2.11$ & $\mathrm{~B}$ \\
\hline LSD & N.S & 13.44 & 6.21 \\
\hline
\end{tabular}

\section{Level of blood lipid}

Table 2 show the level of blood lipid was significantly change that include total of cholesterol also triglyceride and low density lipo protein and high density lipoprotein, opposite to control group . The results in table revealed that HDL-cholesterol was significantly decreased $(\mathrm{P}<0.05)$ while total cholesterol, triglyceride and low density lipoprotein were increased significantly $(\mathrm{P}<0.05)$ in group with hyperlipidemia to compared with control and other of treated groups. Changes in lipid profile are reversed and their values became insignificantly $(\mathrm{P}<0.05)$ near the value of control group when rats treated by bay leave extract $250 \mathrm{mg} / \mathrm{kg}$ and $6.0 \mathrm{mg} / \mathrm{kg}$ of atorvastatin.

Table (2) Effect of bay leave extract and atorvastatin on hyperlipidemia male rats on serum Lipid Profile, $($ Mean \pm SD) $n=10$

\begin{tabular}{|c|c|c|c|c|}
\hline The groups & $\begin{array}{c}\mathrm{TC} \\
\mathrm{mg} / \mathrm{dL}\end{array}$ & $\begin{array}{c}\text { TG } \\
\mathrm{mg} / \mathrm{dL}\end{array}$ & $\begin{array}{c}\text { HDL } \\
\mathrm{mg} / \mathrm{dL}\end{array}$ & $\begin{array}{c}\text { LDL } \\
\mathrm{mg} / \mathrm{dL}\end{array}$ \\
\hline Control group & $\begin{array}{c}86.91 \pm 5.44 \\
\text { b }\end{array}$ & $\begin{array}{c}71.19 \pm 4.21 \\
\text { B }\end{array}$ & $29.11 \pm 1.05 \mathrm{a}$ & $\begin{array}{c}21.18 \pm 2.33 \\
\text { B }\end{array}$ \\
\hline HFD $2 \%$ cholesterol & $188.11 \pm 4.14 \mathrm{a}$ & $171.13 \pm 4.61 \mathrm{a}$ & $19.61 \pm 1.15 \mathrm{c}$ & $\begin{array}{c}41.01 \pm 2.11 \\
\mathrm{~A}\end{array}$ \\
\hline BLE $250 \mathrm{mg} / \mathrm{kg}$ & $\begin{array}{c}91.23 \pm 5.11 \\
b\end{array}$ & $\begin{array}{c}68.14 \pm 4.19 \\
\text { B }\end{array}$ & $\begin{array}{c}28.91 \pm 1.25 \\
\text { B }\end{array}$ & $\begin{array}{c}20.18 \pm 2.71 \\
\text { B }\end{array}$ \\
\hline Atorvastatin $20 \mathrm{mg} / \mathrm{kg}$ & $\begin{array}{c}89.01 \pm 4.61 \\
\text { b }\end{array}$ & $\begin{array}{c}62.052 \pm 3.81 \\
\text { B }\end{array}$ & $\begin{array}{c}33.17 \pm 1.13 \\
\mathrm{~A}\end{array}$ & $\begin{array}{c}19.34 \pm 3.185 \\
\text { B }\end{array}$ \\
\hline LSD & 6.14 & 4.65 & 3.07 & 3.24 \\
\hline
\end{tabular}

\section{Liver function test:}

As illustrated in table (3) the results of enzyme ALT and AST in serum were significantly increase $(\mathrm{p} \leq 0.05)$ in HFD and group of animals treated $20 \mathrm{mg} / \mathrm{kg}$ bw atorvastatin compared with control and group of animal 
treated extract of BLE with $250 \mathrm{mg}$ per $\mathrm{kg}$ of body weight, also the table showed ameliorative effect of BLE $250 \mathrm{mg} / \mathrm{kg}$.Bw and $20 \mathrm{mg} / \mathrm{kg} \mathrm{Bw}$. atorvastatin in
ALP enzyme when appeared increased significantly in group of animals treated HFD to compared by control group .

Table (3): Effect of bay leave and atorvastatin about the ALT, AST and ALP enzyme Mean \pm SD) $n=10$

\begin{tabular}{|c|c|c|c|}
\hline Groups & ALT (U/L) & $\operatorname{AST}(\mathrm{U} / \mathrm{L})$ & ALP (IU/L) \\
\hline Control & $\begin{array}{c}25.51 \pm 1.87 \\
\mathrm{C}\end{array}$ & $\begin{array}{c}19.06 \pm 1.03 \\
\mathrm{C}\end{array}$ & $\begin{array}{c}25.32 \pm 2.48 \\
\text { B }\end{array}$ \\
\hline HFD $2 \%$ cholesterol & $\begin{array}{c}52.17 \pm 4.51 \\
\mathrm{~A}\end{array}$ & $\begin{array}{c}56.18 \pm 4.45 \\
\mathrm{~A}\end{array}$ & $\begin{array}{c}36.28 \pm 2.41 \\
\mathrm{~A}\end{array}$ \\
\hline BLE $250 \mathrm{mg} / \mathrm{kg}$ & $\begin{array}{c}24.12 \pm 1.21 \\
C\end{array}$ & $\begin{array}{c}20.06 \pm 2.01 \\
C\end{array}$ & $\begin{array}{c}26.18 \pm 1.07 \\
b\end{array}$ \\
\hline $\begin{array}{l}\text { Atorvastatin } \\
20 \mathrm{mg} / \mathrm{kg}\end{array}$ & $\begin{array}{c}33.33 \pm 2.14 \\
\text { B }\end{array}$ & $\begin{array}{c}28.62 \pm 1.81 \\
\text { B }\end{array}$ & $\begin{array}{c}28.17 \pm 2.41 \\
\text { B }\end{array}$ \\
\hline LSD & 3.23 & 4.25 & 3.65 \\
\hline
\end{tabular}

\section{Kidney function}

A significantly $\mathrm{p}$-value $(\mathrm{p} \leq 0.05)$ increased concentration of serum urea in blood concentration was noticed at treated the animals by HFD compared to control and rats treated by bay leave extract $250 \mathrm{mg} / \mathrm{kg}$ and 6.0 $\mathrm{mg} / \mathrm{kg}$ of atorvastatin table (4). Also these tables show significantly $\mathrm{p}$-value $(\mathrm{p} \leq 0.05)$ increased concentration of serum creatinine was recorded at HFD animal's treatment compared with control and other treated groups.

Table (4) : Effect of bay leave and atorvastatin on urea and createnin. (Mean $\pm \mathbf{s d}) \mathbf{n}=\mathbf{1 0}$

\begin{tabular}{|c|c|c|}
\hline Group & $\begin{array}{c}\text { Urea } \\
\mathrm{mg} / \mathrm{dL}\end{array}$ & $\begin{array}{c}\text { Creatinen } \\
\text { mg/dL }\end{array}$ \\
\hline Control & $\begin{array}{c}21.25 \pm 2.18 \\
\mathrm{C}\end{array}$ & $\begin{array}{c}0.51 \pm 0.02 \\
\text { B }\end{array}$ \\
\hline HFD $2 \%$ cholesterol & $\begin{array}{c}61.57 \pm 3.86 \\
\mathrm{~A}\end{array}$ & $\begin{array}{c}1.12 \pm 0.13 \\
\mathrm{~A}\end{array}$ \\
\hline BLE $250 \mathrm{mg} / \mathrm{kg}$ & $\begin{array}{c}28.72 \pm 3.15 \\
\text { B }\end{array}$ & $\begin{array}{c}0.31 \pm 0.01 \\
\mathrm{C}\end{array}$ \\
\hline $\begin{array}{c}\text { Atorvastatin } \\
20 \mathrm{mg} / \mathrm{kg}\end{array}$ & $\begin{array}{c}18.55 \pm 1.89 \\
\mathrm{C}\end{array}$ & $\begin{array}{c}0.22 \pm 0.08 \\
\mathrm{C}\end{array}$ \\
\hline LSD & 3.11 & 0.11 \\
\hline
\end{tabular}




\section{Discussion}

Objective of the study was comparing Laurusnobilis extract with Atorvastatin on the rats as type of diet with high fat (HFD). Induced hyperlipidemia caused increased in weigh and weigh gain. The results agree with Cláudia and his coworkers ${ }^{11}$, they obtained that diet with high fat lead to improve energy ingestion, also the weight gain, and body fat mass. Feeding Rats by diet with high fat taking with higher amounts of food, also the higher amounts for energy with study when discussed group the feeding rats with the standard of the diet. The body weight gain was higher at those animals and may be due to relaxation of the adipose tissues, also maybe high fat diet effect on the Leptin which is hormone adipocyte-derived which controls on food intake and expenditure of energy ${ }^{12}$. The concentration of leptin in plasma increased at proportion of body fat mass. Diet with high fat of feeding in rodent related to increase in consumption of food $^{13}$.Mechanism of overeating, (hyperplasia) and subsequent weight gain in diet with high fat fed animal types and human results a matter of debate ${ }^{14}$. In our study that the methanolic leaf extracts of Laurusnobilis administrated that ameliorate increased of the body weight gain in group with hyprlipidaemia. Due to that Laurus with leaf extracts increase the clipids which is accumulated in adipose tissue resulting in ameliorate body weight. For our study, increased significantly body weight of rats treated with atorvastatin with statin use the weight gain not well explained, other results that showed used of the statins lead to large of body and accumulation of hepatic fat at rats with obesity ${ }^{15}$. Other study done by ${ }^{16}$ was reported the weight of body increased post one year of atorvastatin randomization. Term of hypercholesterolemia associated with high concentration of low density lipoprotein and low concentration of high density lipoprotein concentration is common factor for development of atherosclerotic disease, more diet-derived cholesterol is the first cause of hypercholesterolemia ${ }^{17}$. At present study, the rats feeding with diet high fatto 4 weeks exhibited this lead to increase levels of TC and LDL concentration at serum More of data not coordinate with others similar studies ${ }^{18}$ Most resulting of this study showed consumption of BLE daily at doses of $250 \mathrm{mg} / \mathrm{kg}$ and Atorvastatin $20 \mathrm{mg} / \mathrm{kg}$ that improve the serum of hepatic lipid profile, better hepatic function tests, and haptic enzymatic system at diet with high fat on feeding rat type. On the other hand, Atorvastatin known as of 3-hydroxy and 3-methylglutaryl coenzyme A that for reducates inhibitors with very effective on lipidlowering effects in human and animals ${ }^{19}$. Our results also explain that the hypercholesterolemia may be leads to production of fats but not affecting liver function. Other groups of researchers which are using more of diet supplementation showed large severe form of liver injury, it means liver fibrosis that because isolated hypercholesterolemia induced by diet which containing $2 \%$ of cholesterol, for 2 weeks in Westar rats $^{20}$. Present findings to confirm these aforementioned studies showing that isolated of hypercholesterolemia lead to liver injury, presence of cholesterol in diet is necessary for triglyceride accumulation in the liver, as $5 \%$ dietary fat alone has no such effect ${ }^{21}$. The BLE treated group showed decreased ALT, AST and ALP enzyme level that maybe due to hepato protective properties of the BLE. That is probably due to presence and combined action of the extract phytocomponents which have non flavonoid in origin such as, terpenes and terpenoids possessing anti oxidative also antimicrobial activities ${ }^{22}$.

The statins mainly in the liver are metabolized and increase the levels of aminotransferases with liver potential toxicity that may be attributed to alteration of hepatocyte cellular membrane rather than direct liver injury, the increased level of ALP also AST and ALT that indicate these enzymes outside from liver into the blood stream and indicated the tissue was harm, which is associated 
with necrosis of liver $^{23}$. Alanin amino transferase is found throughout the cytoplasm, whereas part at amino transferase is found in the mitochondria. In case of liver stress, mitochondria damage with ROS accumulation tends to increase the level of AST rather than ALT ${ }^{24}$.

Conclusion: bay leave exerts and atorvastatin have amelioration effect against hyperlipidemia in HFD-fed rats.

\section{Conflict of Interest: Nil}

\section{Source of Funding: Self}

Ethical Clearance: It was given by the institution.

\section{References}

1- Navar-Boggan AM, Peterson ED, D'Agostino RB Sr, Neely B, Sniderman AD, Pencina MJ. Hyperlipidemia in early adulthood increases longterm risk of coronary heart disease. Circulation. 2015;131(5):451-458. doi:10.1161/ CIRCULATIONAHA.114.012477

2- Xu QY, Liu YH, Zhang Q, et al. Metabolomic analysis of simvastatin and fenofibrate intervention in high-lipid diet-induced hyperlipidemia rats. Acta Pharmacol Sin. 2014; 35(10):1265-1273. doi:10.1038/aps.2014.72

3- Jacobson MS .Heart healthy diets for all children: No longer controversial. J Pediatr .1998; 133: 1-2.

4- Johnson MC. Hyperlipidemia disorders in dogs. Compendium. 2005; 27 (5): 361-370.

5- Roberts W.C. Preventing and arresting coronary atherosclerosis. Am Heart $J$.1995; 130:580-600. https://doi.org/10.1016/0002-8703(95)90369-0

6- Ahn J, Kim NS, Lee BK, Park S .Carbohydrate intake exhibited a positive association with the risk of metabolic syndrome in both semi-quantitative food frequency questionnaires and $24 \mathrm{~h}$ recall in women. J Korean Med Sci.2017; 32: 1474-1483.

7- Xenoulis PG, Steiner JM. Lipid metabolism and hyperlipidemia in dogs. Vet $J$.2010; 183: 12-21.

8- Durham A .Clinical application of parenteral nutritioninthetreatmentoffiveponiesandonedonkey with hyperlipemia. Vet Record. 2006; 158:159-64.

9- Klein S, Coppack SW, Mohamed-Ali V, Landt M.Adipose tissue leptin production and plasma leptin kinetics in humans. Diabetes 1; 1996; 45:984-7; PMID: 8666153.

10- Klok MD, Jakobsdottir S, Drent ML .The role of leptin and ghrelin in the regulation of food intake and body weight in humans: a review. Obesity Rev .2007; 8:21-34; PMID: 17212793; http://dx.doi. org/10.1111/j.1467-789X.00270.x.

11- Marques C, Meireles $M$, Norberto $S$, et al. High-fat diet-induced obesity Rat model: a comparison between Wistar and Sprague-Dawley Rat. Adipocyte. 2015; 5(1):11-21. Published 2015 Jul 15. doi:10.1080/21623945.2015.1061723

12- Lutz TA, Woods SC. Overview of animal models of obesity. Curr Protoc Pharmacol. 2012; Chapter 5:Unit5.61. doi:10.1002/0471141755.ph0561s58.

13- Aguirre L, Hijona E, Macarulla MT et al. Several statins increase body and liver fat accumulation in a model of metabolic syndrome. $J$ Physiol Pharmcol. 2013; 64: 281-288.

14- Ong KL, Waters DD, Messig M, DeMicco DA, Rye KA, Barter PJ. Effect of change in body weight on incident diabetes mellitus in patients with stable coronary artery disease treated with atorvastatin (from the treating to new targets study). Am J Cardiol.2014; 113: 1593- 1598.

15- Braamskamp MJ, Hutten BA and Wiegman A . Early initiation of statin treatment in children with familial hypercholesterolaemia. Curr Opin Lipidol. $20.15 ; 26: 236-239$.

16- Yakushiji E, Ayaori M, Nishida T, Shiotani K, Takiguchi S, Nakaya K, Uto-Kondo H, Ogura M, Sasaki M, Yogo M, et al .Probucol-oxidized products, spiroquinone and diphenoquinone, promote reverse cholesterol transport in mice. Arterioscler Thromb Vasc Biol. 20.16; 36:591-597.

17- Jin C.J., Engstler A.J., Ziegenhardt D., Bischoff S.C., Trautwein C., Bergheim I. Loss of lipopolysaccharide-binding protein attenuates the development of diet-induced non-alcoholic fatty liver disease in mice. J. Gastroenterol. Hepatol. 2017; 32(3):708-715. 
18- Khaleel EF, Abdel-Aleem GA, Mostafa DG. Resveratrol improves high-fat diet induced fatty liver and insulin resistance by concomitantly inhibiting proteolytic cleavage of sterol regulatory element-binding proteins, free fatty acid oxidation, and intestinal triglyceride absorption. Can J Physiol Pharmacol. 2017; 96(2):145-157.

19- Yan MX, Li YQ, Meng M, Ren HB, Kou Y. Longterm high-fat diet induces pancreatic injuries via pancreatic microcirculatory disturbances and oxidative stress in rats with hyperlipidemia. Biochem Biophys Res Commun. 2006; 347:192-9.

20- Kovár J, Tonar Z, Heczková M, Poledne R. Prague hereditary hypercholesterolemic [PHHC] rat - a model of polygenic hypercholesterolemia. Physiol Res. 2009; 58:S95-9.
21- Vardapetyan H, Tiratsuyan S, Hovhannisyan A, Rukhkyan M Hovhannisyan D.Phytochemical composition and biological activityofLaurusnobilis L. leaves collected from two regions of South Caucasus, J Expe Biol Agricul Sci. 2013; 1:45-51.

22- Zainab S. Study of the Protective Effect of Ginger Extracts Against hepatic Induced by Carbon Tetrachloride in Rats. A thesis in physiology, 2013. Faculty of Science / University of Kufa, Iraq.

23- Sampson UK, Linton MF, Fazio S. Are statins diabetogenic?. Curr Opin Cardiol. 2011;26(4):342347. doi:10.1097/HCO.0b013e3283470359.

24- $\mathrm{Hu} \mathrm{Z}$, Lausted C, Yoo H, et al. Quantitative liverspecific protein fingerprint in blood: a signature for hepatotoxicity. Theranostics. 2014;4(2):215-228. Published 2014 Jan 14. doi:10.7150/thno.7868 